Recognition Odysseys 
NARRATING NATIVE HISTORIES

Series editors

K. Tsianina Lomawaima

Florencia E. Mallon

Alcida Rita Ramos

Joanne Rappaport

Editorial Advisory Board

Denise Y. Arnold

Charles R. Hale

Roberta Hill

Noenoe K. Silva

David Wilkins

Juan de Dios Yapita 


\title{
RECOGNITION ODYSSEYS
}

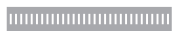 \\ Indigeneity, Race, and Federal Tribal Recognition Policy \\ in Three Louisiana Indian Communities
}

\section{Brian Klopotek}

Duke University Press

Durham and London

$20 I I$ 


\section{(C) 20II Duke University Press}

All rights reserved.

Printed in the United States of America on acid-free paper $\infty$ Designed by Heather Hensley

Typeset in Monotype Dante by Keystone Typesetting, Inc.

Library of Congress Cataloging-in-Publication Data appear on the last printed page of this book. 